Kunal Deokar, Mehul Agarwal, Naveen Dutt, Nishant Chauhan, Ram Niwas, Benhur Joel Shadrach, Gopal Chawla

Department of Pulmonary Medicine, All India Institute of Medical Sciences, Jodhpur, India

\title{
A review of ciclesonide in the management of COVID-19. Still a long way to go
}

To the Editor

COVID-19 has spread throughout the world infecting 8,018,963 people and claiming 436,138 lives to date [1]. No definitive therapy is yet available. Numerous drugs and therapies are under investigation. One such drug is ciclesonide. It is an inhaled corticosteroid which is used in the management of bronchial asthma [2]. It has shown good anti-viral activity against SARS$\mathrm{CoV}-2$ in in vitro studies [3, 4]. It has been speculated that the anti-inflammatory and antiviral activity of Ciclesonide may play a beneficial role in mild to moderate cases of COVID-19.

The exact mechanism of the antiviral activity of ciclesonide is not yet known. Ciclesonide inhibits viral replication by targeting the viral endoribonuclease NSP15 [4]. Ciclesonide is a p21 activated kinase (PAK)-1 blocker and this may result in inhibition of SARS-CoV-2 replication. p21 activated kinases (PAK) are a family of 6 serine/threonine protein kinases involved in intracellular signalling by acting as downstream effectors of the small GTPases Cdc42 and Rac. They play a vital role in cell proliferation, survival, and motility. Several viruses are known to activate PAK so as to enter the cell and gain control over its biological machinery [5]. Certain viruses are also known to exploit PAK-mediated signalling to facilitate spread from one cell to another by formation of membrane nanotubes [6, 7]. SARS-CoV-2 has also been speculated to exploit PAK-1 signalling [8]. By blocking PAK-1, ciclesonide inhibits SARS-CoV-2 replication.

We searched PubMed using the terms "ciclesonide", "SARS-CoV-2", "COVID-19", and "corona virus" and found only one report describing the use of ciclesonide in three cases [9]. All three cases had pneumonia and required oxygen support at 1-2 L/min. All 3 cases improved clinically after starting ciclesonide. Fever resolved, oxygenation improved, and radiological improvement was seen in these patients. The dose used was $200 \mu \mathrm{g}$ twice daily and was increased to $400 \mu \mathrm{g}$ twice daily in one patient, and $400 \mu \mathrm{g}$ thrice daily in two patients.

A search on clinicaltrials.gov and the World Health Organization-International Clinical Trial Registry Platform (WHO ICTRP) revealed 6 clinical trials (Table 1). The CONTAIN trial is a randomised, placebo-controlled trial in which the efficacy of inhaled and intranasal ciclesonide in patients with mild COVID-19 will be studied. Korean university Guro hospital will study the efficacy of ciclesonide alone or in combination with hydroxychloroquine for adults with mild COVID-19 in an open-labelled, randomized clinical trial. The dose of inhaled ciclesonide used will be $320 \mu \mathrm{g}$ twice daily via a metered dose inhaler (MDI) for 14 days. The primary outcome studied will be the rate of SARS-CoV-2 eradication at day 14 from study enrolment. Covis pharma has initiated a phase 3 , multi-center, randomized, double-blind, placebo-controlled trial. The dose of inhaled ciclesonide used is $320 \mu \mathrm{g}$ twice daily via a metered dose inhaler (MDI) for 30 days. The primary outcome studied will be the percentage of patients requiring hospital admission or death by day 30. In the HALT COVID-19 study, patients will be randomized and allocated in a 1:1 ratio into ciclesonide $320 \mu \mathrm{g}$ twice daily or standard of care groups. The primary outcome studied will be the duration of the requirement of supplemental

Address for correspondence: Kunal Deokar; All India Institute of Medical Sciences, Jodhpur, India, e-mail: dkunal@live.in

DOI: 10.5603/ARM.a2020.0173

Received: 11.07.2020

Copyright (C) 2021 PTChP

ISSN 2451-4934 
oxygen therapy. In an open label, randomised trial from India, the efficacy of hydroxychloroquine, ciclesonide, and ivermectin in the treatment of moderate COVID-19 illness will be assessed. The primary outcome studied will be the proportion of patients having a virologic cure on day 6 in each of the groups. The RACCO trial is a multi-center, open-label, randomized trial to evaluate the effi-

Table 1. Summary of clinical trials registered under the United States National Library of Medicine clinical trials registry and WHO International Clinical Trials Registry Platform on ciclesonide for COVID-19

\begin{tabular}{|c|c|c|c|c|c|c|c|}
\hline $\begin{array}{l}\text { Clinical trial } \\
\text { identifier }\end{array}$ & Country & Title & Study design & Patient group & Intervention & $\begin{array}{c}\text { Primary } \\
\text { outcome } \\
\text { measures }\end{array}$ & $\begin{array}{c}\text { Recruitment } \\
\text { status }\end{array}$ \\
\hline NCT04435795 & Canada & $\begin{array}{c}\text { CONTAIN } \\
\text { (CiclesOnide cliNi- } \\
\text { cal TriAl } \\
\text { for COVID-19 } \\
\text { treatmeNt) }\end{array}$ & $\begin{array}{l}\text { Randomized, } \\
\text { placebo } \\
\text { controlled }\end{array}$ & $\begin{array}{l}\text { Laboratory con- } \\
\text { firmed COVID-19 } \\
\text { positive adults } \\
\text { more than } \\
18 \text { years of age, } \\
\text { within } 5 \text { days of } \\
\text { laboratory diagno- } \\
\text { sis, not severely } \\
\text { ill and who are } \\
\text { at home on day } 0\end{array}$ & $\begin{array}{l}\text { Intranasal } \\
\text { ciclesonide to } \\
\text { each nostril } \\
\text { and inhaled } \\
\text { cilcesonide vs } \\
\text { normal saline } \\
\text { intranasal BID } \\
\text { and placebo } \\
\text { MDI inhaled }\end{array}$ & $\begin{array}{l}\text { Improvemet } \\
\text { in dyspnea } \\
\text { at day } 7\end{array}$ & $\begin{array}{l}\text { Not yet } \\
\text { recruiting }\end{array}$ \\
\hline NCT04330586 & Korea & $\begin{array}{l}\text { A trial of cicle- } \\
\text { sonide alone or } \\
\text { in combination } \\
\text { with hydroxy- } \\
\text { chloroquine for } \\
\text { adults with mild } \\
\text { COVID-19 }\end{array}$ & $\begin{array}{c}\text { Multi- } \\
\text { center,open } \\
\text { label } \\
\text { randomized }\end{array}$ & $\begin{array}{l}\text { Laboratory con- } \\
\text { firmed COVID-19 } \\
\text { positive adults } \\
18 \text { to } 80 \text { years } \\
\text { with mild } \\
\text { COVID-19 (NEWS } \\
\text { scoring system } \\
\text { 0-4) and within } \\
7 \text { days from } \\
\text { symptom onset } \\
\text { or within } \\
48 \text { hours of labo- } \\
\text { ratory diagnosis }\end{array}$ & $\begin{array}{l}\text { Ciclesonide } \\
\text { vs ciclesonide } \\
\text { and hydroxy- } \\
\text { chloroquine } \\
\text { vs control }\end{array}$ & $\begin{array}{c}\text { Rate of } \\
\text { SARS-CoV-2 } \\
\text { eradication } \\
\text { at day } 14\end{array}$ & $\begin{array}{l}\text { Not yet } \\
\text { recruiting }\end{array}$ \\
\hline NCT04377711 & $\begin{array}{l}\text { United } \\
\text { States }\end{array}$ & $\begin{array}{l}\text { A phase 3, mul- } \\
\text { ticenter, random- } \\
\text { ized, double-blind, } \\
\text { placebo-controlled } \\
\text { study to assess } \\
\text { the safety and } \\
\text { efficacy of } \\
\text { ciclesonide me- } \\
\text { tered-dose inhaler } \\
\text { in non-hospitalized } \\
\text { patients } \\
12 \text { years of age } \\
\text { and older with } \\
\text { symptomatic } \\
\text { COVID-19 } \\
\text { infection }\end{array}$ & $\begin{array}{l}\text { Multicenter, } \\
\text { double-blind, } \\
\text { randomized, } \\
\text { placebo-con- } \\
\text { trolled }\end{array}$ & $\begin{array}{l}\text { Laboratory con- } \\
\text { firmed COVID-19 } \\
\text { positive adults } \\
\text { more than } \\
12 \text { years of age, } \\
\text { within } 72 \text { hours } \\
\text { of laboratory } \\
\text { diagnosis, } \\
\text { not hospitalized, } \\
\text { but symptomatic } \\
\text { with oxygen } \\
\text { saturation > 93\% } \\
\text { and able to take } \\
\text { MDI }\end{array}$ & $\begin{array}{l}\text { Ciclesonide } \\
\text { vs placebo }\end{array}$ & $\begin{array}{l}\text { Percentage } \\
\text { of patient's } \\
\text { with hospital } \\
\text { admission } \\
\text { or death by } \\
\text { day } 30\end{array}$ & Recruiting \\
\hline NCT04381364 & Sweden & $\begin{array}{l}\text { Inhalation of cicle- } \\
\text { sonide for patients } \\
\text { with COVID-19: } \\
\text { A randomised } \\
\text { open treatment } \\
\text { study (HALT } \\
\text { COVID-19) }\end{array}$ & $\begin{array}{l}\text { Multicenter, } \\
\text { double-blind } \\
\text { randomized }\end{array}$ & $\begin{array}{c}\text { Adults } 18 \text { to } \\
85 \text { years of age } \\
\text { that are hospital- } \\
\text { ized and require } \\
\text { oxygen therapy, } \\
\text { within } 48 \text { hours } \\
\text { of diagnosis } \\
\text { by a physician } \\
\text { based on clinical } \\
\text { and radiological } \\
\text { findings }\end{array}$ & $\begin{array}{l}\text { Ciclesonide } \\
\text { vs standard } \\
\text { of care }\end{array}$ & $\begin{array}{l}\text { Duration of } \\
\text { supplemental } \\
\text { oxygen thera- } \\
\text { py received }\end{array}$ & $\begin{array}{l}\text { Not } \\
\text { recruiting }\end{array}$ \\
\hline
\end{tabular}




\begin{tabular}{|c|c|c|c|c|c|c|c|}
\hline $\begin{array}{l}\text { CTRI/2020/04/ } \\
\text { /024948 }\end{array}$ & India & $\begin{array}{l}\text { Efficacy of hy- } \\
\text { droxychloroquine, } \\
\text { ciclesonide } \\
\text { and ivermectin } \\
\text { in treatment } \\
\text { of moderate } \\
\text { COVID-19 illness: } \\
\text { an open-label } \\
\text { randomised } \\
\text { controlled study }\end{array}$ & $\begin{array}{l}\text { Open-label, } \\
\text { randomised }\end{array}$ & $\begin{array}{l}\text { Laboratory con- } \\
\text { firmed COVID-19 } \\
\text { positive adults } \\
\geq 18 \text { years with } \\
\text { presence of mod- } \\
\text { erate COVID-19 } \\
\text { disease as de- } \\
\text { fined by presence } \\
\text { of pneumonia } \\
\text { (clinical and ra- } \\
\text { diological signs) } \\
\text { with respiratory } \\
\text { rate between } 15 \\
\text { to } 30 / \text { minute and/ } \\
\text { /or } \mathrm{SpO}_{2} 90-94 \% \\
\text { on room air. }\end{array}$ & $\begin{array}{l}\text { Hydroxychlo- } \\
\text { roquine vs } \\
\text { ciclesonide } \\
\text { vs ivermectin } \\
\text { vs standard } \\
\text { of care }\end{array}$ & $\begin{array}{l}\text { Proportion of } \\
\text { patients hav- } \\
\text { ing virologic } \\
\text { cure on day } 6\end{array}$ & $\begin{array}{l}\text { Not } \\
\text { recruiting }\end{array}$ \\
\hline jRCTs031190269 & Japan & $\begin{array}{l}\text { A multicenter, } \\
\text { open-label, } \\
\text { randomized trial } \\
\text { to evaluate the } \\
\text { efficacy and } \\
\text { safety of inhaled } \\
\text { ciclesonide for } \\
\text { asymptomatic } \\
\text { and mild patients } \\
\text { with COVID-19 } \\
\text { (RACCO trial) }\end{array}$ & $\begin{array}{l}\text { Open-label, } \\
\text { randomised }\end{array}$ & $\begin{array}{l}\text { Laboratory con- } \\
\text { firmed COVID-19 } \\
\text { positive adults } \\
\text { more than } 12 \\
\text { years of age, who } \\
\text { have no apparent } \\
\text { pneumonia due } \\
\text { to COVID-19 on } \\
\text { plain chest radio- } \\
\text { graphs, who can } \\
\text { be hospitalized, } \\
\text { who can inhale } \\
\text { using inhalation } \\
\text { assist device }\end{array}$ & $\begin{array}{l}\text { Ciclesonide } \\
\text { vs standard } \\
\text { of care }\end{array}$ & $\begin{array}{l}\text { Pneumonia } \\
\text { incidence } \\
\text { on day } 8 \text { of } \\
\text { ciclesonide } \\
\text { inhalation }\end{array}$ & Recruiting \\
\hline
\end{tabular}

cacy and safety of inhaled ciclesonide for asymptomatic and mild patients. The primary outcome studied will be the incidence of pneumonia on day 8 of ciclesonide inhalation.

Thus, at present, the evidence regarding the role of ciclesonide in COVID-19 is limited to in-vitro studies and a case report. Results from randomised controlled trials are awaited. Though in-vitro studies have shown anti-SARS-CoV-2 activity of ciclesonide, it will be exciting to see if these translate into better clinical outcomes for patients with COVID-19.

\section{Conflict of interest}

None declared.

\section{References:}

1. Worldometers. Available online: www.worldometers.info/coronavirus/. [Last accessed at: 15.07.2020].

2. Global Initiative for Asthma. Global strategy for asthma management and prevention. Updated 2020. Available online: https:/ginasthma.org/wp-content/uploads/2020/06/GINA-2020report_20_06_04-1-wms.pdf.[Last accessed at: 13.07.2020].
3. Jeon S, Ko M, Lee J, et al. Identification of antiviral drug candidates against SARS-CoV-2 from FDA-approved drugs. Antimicrob Agents Chemother. 2020; 64(7), doi: 10.1128/AAC.0081920, indexed in Pubmed: 32366720 .

4. Matsuyama S, Kawase M, Nao N, et al. The inhaled corticosteroid ciclesonide blocks coronavirus RNA replication by targeting viral NSP15. Available online: www.biorxiv.org/content/10.1101/2020.03.11.987016v1.full.pdf. [Last accessed at: 13.07.2020]. , doi: 10.1101/2020.03.11.987016.

5. Van den Broeke C, Radu M, Chernoff J, et al. An emerging role for p21-activated kinases (Paks) in viral infections. Trends Cell Biol. 2010; 20(3): 160-169, doi: 10.1016/j.tcb.2009.12.005, indexed in Pubmed: 20071173.

6. Finnen RL, Roy BB, Zhang H, et al. Analysis of filamentous process induction and nuclear localization properties of the HSV-2 serine/threonine kinase Us3. Virology. 2010; 397(1): 23-33, doi: 10.1016/j.virol.2009.11.012, indexed in Pubmed: 19945726.

7. Van den Broeke C, Radu M, Deruelle M, et al. Alphaherpesvirus US3-mediated reorganization of the actin cytoskeleton is mediated by group A p21-activated kinases. Proc Natl Acad Sci U S A. 2009; 106(21): 8707-8712, doi: $10.1073 /$ pnas.0900436106, indexed in Pubmed: 19435845.

8. Maruta H, He H. PAK1-blockers: potential therapeutics against COVID-19. Med Drug Discov. 2020; 6: 100039, doi: 10.1016/i. medidd.2020.100039, indexed in Pubmed: 32313880.

9. Iwabuchi K, Yoshie K, Kurakami Y, et al. Therapeutic potential of ciclesonide inahalation for COVID-19 pneumonia: Report of three cases. J Infect Chemother. 2020; 26(6): 625-632, doi: 10.1016/j.jiac.2020.04.007, indexed in Pubmed: $\underline{2362440 .}$ 